\title{
Determination of soil specific surface area by water vapor adsorption III Comparison of surface areas determined by water vapor and nitrogen gas adsorption
}

\section{RAINA NISKANEN ${ }^{1}$ and VÄINÖ MÄNTYLAHTI ${ }^{2}$}

${ }^{\prime}$ Department of Agricultural Chemistry, University of Helsinki, SF-00710 Helsinki, Finland

${ }^{2}$ Viljavuuspalvelu Oy (Soil Analysis Service Ltd.), Vellikellontie 4, -

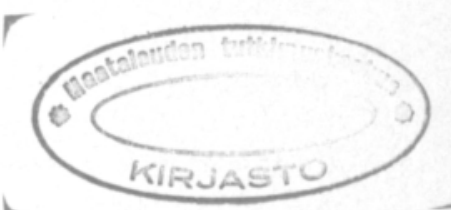
SF-00410 Helsinki, Finland

\begin{abstract}
The specific surface areas of ten soil samples (clay content $1-72 \%$, organic carbon content $0.8-11.5 \%$ ) were determined by water vapor and nitrogen gas adsorption. The surface areas obtained by application of the BET equation to water vapor sorption at $\mathrm{p} / \mathrm{p}_{\mathrm{o}}$ $0.12-0.42\left(21-195 \mathrm{~m}^{2} / \mathrm{g}\right)$ were, on the average, $80 \%$ of the areas determined by water vapor sorption at $\mathrm{p} / \mathrm{p}_{\mathrm{o}} 0.20$, range $27-229 \mathrm{~m}^{2} / \mathrm{g}$. A BET water monolayer coverage was formed on the soil surface at $\mathrm{p} / \mathrm{p}_{\mathrm{o}} 0.12-0.20$. The BET water area correlated closely with the one-point water area $\left(\mathrm{p} / \mathrm{p}_{0} 0.20\right)$. The surface area determined by nitrogen gas adsorption ranged from 0.3 to $21 \mathrm{~m}^{2} / \mathrm{g}$ and did not correlate closely with water areas. The water surface areas were closely related to soil organic carbon content, while the nitrogen area was primarily related to soil clay content.
\end{abstract}

Index words: gas adsorption, BET equation, monolayer coverage, relative humidity, mineral soils

\section{Introduction}

The specific surface area of soils and clays is conventionally determined by low-temperature adsorption isotherms of non-polar gases like nitrogen. Adsorption of polar molecules like water is also used for estimation of soil surface area. In addition to application of water adsorption isotherms, one-point methods are developed. According to QUIRK (1955), surface areas determined by water vapor adsorption are only approximations to the areas determined by nitrogen adsorption. In this connection, areas determined by onepoint adsorption of water at a relative humidity $\left(\mathrm{p} / \mathrm{p}_{\mathrm{o}}\right)$ of $20 \%$ are as useful as areas determined by water vapor adsorption isotherms. The disagreement of surface areas determined by water vapor and nitrogen adsorption is explained to be due to the fact that only the external area is estimated by nitrogen adsorption, while water vapor adsorption estimates the total surface area 
(van OlPHEN 1975). The previous study (NISKANEN and MÄNTYLAHTI 1987 a) showed that soil surface areas determined by water vapor adsorption at $\mathrm{p} / \mathrm{p}_{\mathrm{o}} 20 \%$ were closely related to soil clay and organic carbon content. The aim of this investigation was to study water vapor sorption on soil and to compare surface areas determined by the aid of water vapor sorption isotherms and by water vapor sorption at $\mathrm{p} / \mathrm{p}_{\mathrm{o}} 0.20$ with areas determined by nitrogen gas adsorption.

\section{Material and methods}

The material consisted of ten soil samples which were air-dried and ground to pass a 2-mm sieve. The particle-size distribution of the inorganic matter was determined by the pipette method (ELONEN 1971) and the organic carbon content by a modified (GRAHAM 1948) Alten wet combustion method.

For the determination of water vapor adsorption-desorption isotherms, $1 \mathrm{~g}$ of soil in a tared weighing bottle was equilibrated at $20{ }^{\circ} \mathrm{C}$ in a desiccator over solutions controlling relative humidities $\left(\mathrm{p} / \mathrm{p}_{\mathrm{o}}\right) \quad 0.0-0.97$ (Table 1). After equilibration for 2 weeks the soil + weighing bottle was weighed and thereafter placed over solution controlling the higher (adsorption) or lower (desorption) relative humidity. In the end, soil was dried for 4 hours at $105{ }^{\circ} \mathrm{C}$ (NISKANEN and MÄNTY. LAHTI 1987 b). The experiment was carried out in duplicate.

The soil specific surface area was estimated by the aid of soil water content at $\mathrm{p} / \mathrm{p}_{\mathrm{o}} 0.20$

Table 1. Solutions used for controlling water vapor pressure (GÁl 1967, ANON. 1984).

\begin{tabular}{|c|c|}
\hline Solution & $\begin{array}{l}\text { Relative humidity, } \\
\mathrm{p} / \mathrm{p}_{\mathrm{o}} \text {, at } 20^{\circ} \mathrm{C}\end{array}$ \\
\hline $\mathrm{H}_{2} \mathrm{SO}_{4}$ & 0.0 \\
\hline $\mathrm{H}_{2} \mathrm{SO}_{4}-\mathrm{H}_{2} \mathrm{O}$ mixture (density 1.56 ) & 0.12 \\
\hline Saturated $\mathrm{CH}_{3} \mathrm{COOK}$ & 0.20 \\
\hline $\mathrm{Zn}\left(\mathrm{NO}_{3}\right)_{2} \cdot 6 \mathrm{H}_{2} \mathrm{O}$ & 0.42 \\
\hline $\mathrm{NaNO}_{2}$ & 0.66 \\
\hline $\mathrm{K}_{2} \mathrm{CrO}_{4}$ & 0.88 \\
\hline $\mathrm{K}_{2} \mathrm{SO}_{4}$ & 0.97 \\
\hline
\end{tabular}

(desorption) (NISKANEN and MÄNTYLAHTI 1987 a) and also calculated on the basis of water vapor desorption isotherms $\left(\mathrm{p} / \mathrm{p}_{\mathrm{o}} 0.12-0.42\right)$ by the BET equation (Brunauer et al. 1938). The cross-sectional area of $0.106 \mathrm{~nm}^{2}$ (GÁL 1967) was assigned for a water molecule. Considering the water monolayer on soil surface complete, the water content of $1 \%$ of dry soil corresponds to the surface area of $35.45 \mathrm{~m}^{2} / \mathrm{g}$ dry soil.

The nitrogen BET areas of the samples were measured with a Micromeritics Surface Area Analyzer MIC-2200. The analysis is based on nitrogen gas adsorption at low temperature $\left(-196{ }^{\circ} \mathrm{C}\right)$. At the temperature of liquid nitrogen, the point is measured where the monomolecular layer is adsorbed on the sample. A close-packed arrangement of nitrogen molecules on the surface gives a mean coverage of $0.162 \mathrm{~nm}^{2}$ per $\mathrm{N}_{2}$ molecule (GREGG and SING 1982).

\section{Results and discussion}

Water vapor sorption isotherms (Fig. 1) showed that the equilibrium soil wetness at a given relative humidity was greater in the desorption than in adsorption of water. This hysteresis may be attributed to the geometric non-uniformity of pores, the contact-angle effect, by which the contact angle and the radius of curvature is greater in an advancing meniscus than in a receding one, entrapped air decreasing the water content of newly wetted soil as well as swelling and shrinking (HILLEL 1971). In physical adsorption, usually a hysteresis loop is observed between the adsorption and the desorption isotherms. If the loop does not close at monolayer coverage and below, different values are obtained for the areas derived from the adsorption and desorption isotherm. According to van OLPHEN (1975), the desorption isotherm representing equilibrium more closely, it would be preferable to calculate areas using desorption isotherms.

The sigmoidal form of water sorption 

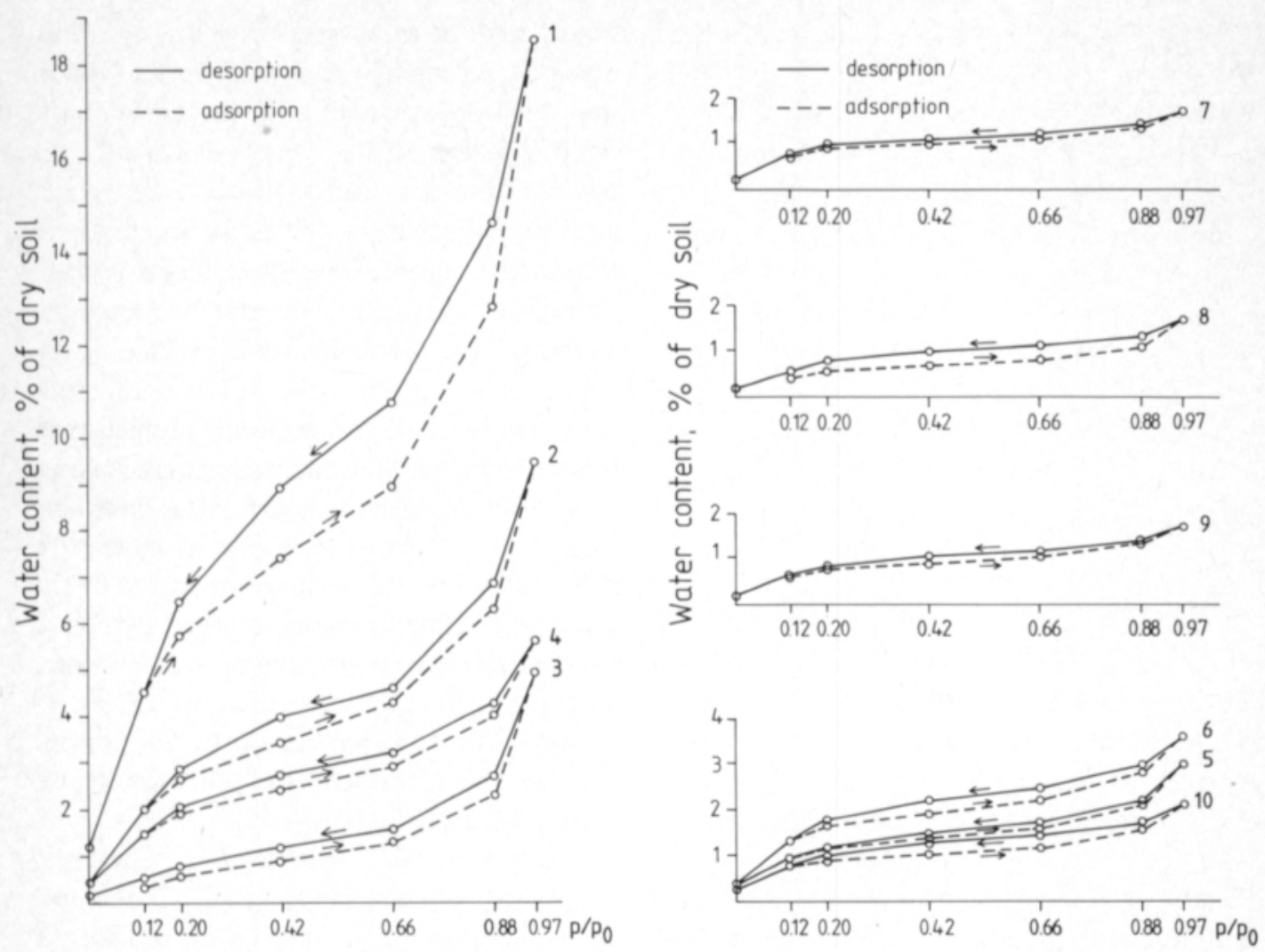

Fig. 1. Water vapor adsorption-desorption isotherms of experimental soils.

isotherms indicates multimolecular adsorption of a physical nature. The amount of water, $\mathrm{w}$, which will sorb onto soil surface at relative humidity $\mathrm{p} / \mathrm{p}_{\mathrm{o}}$, at any temperature $\mathrm{T}$, is dependent on the interaction energy between water and soil and the coverage of the surface. The BET equation (Brunauer et al. 1938), derived for the adsorption of non-polar molecules on solid surfaces, has been applied also to water vapor sorption on soils (e.g. Orchiston 1953, QUirk 1955, PURI and MuRari 1963, Dechnik and Stawínski 1970, Karathanasis and HaJeK 1982, Nieminen and KellomÄKI 1982, NiEMINEN 1985). The main fundamental assumption in the derivation of this equation is that the first layer of gas molecules is attracted to the surface with an energy greater than that of the subsequent layers. The energy of the first layer for a given gas is characteristic of the solid. The heat of subsequent sorption is simply the heat of condensation of the gas with respect to its own liquid phase. The BET equation is written as $\frac{\mathrm{p} / \mathrm{p}_{\mathrm{o}}}{\mathrm{w}\left(1-\mathrm{p} / \mathrm{p}_{\mathrm{o}}\right)}=\frac{\mathrm{C}-1}{\mathrm{w}_{\mathrm{m}} \mathrm{C}} \mathrm{p} / \mathrm{p}_{\mathrm{o}}+\frac{1}{\mathrm{w}_{\mathrm{m}} \mathrm{C}}$ where $w_{m}$ is the quantity of water forming a monolayer and $\mathrm{C}$ is a constant related to the average heat of monolayer adsorption.

In the application of the BET equation to water sorption, $\frac{\mathrm{p} / \mathrm{p}_{\mathrm{o}}}{\mathrm{w}\left(1-\mathrm{p} / \mathrm{p}_{\mathrm{o}}\right)}$ is plotted against $\mathrm{p} / \mathrm{p}_{\mathrm{o}}$. The BET plots of water vapor sorption (desorption) on experimental soils are given in Fig. 2 which shows that the BET equation was obeyed only at low relative humidity. The plots can be considered in broad outline linear at $\mathrm{p} / \mathrm{p}_{\mathrm{o}} 0.12-0.42$. In general, the BET equation is most useful at $\mathrm{p} / \mathrm{p}_{\mathrm{o}} 0.05-0.45$ (MortLand and Kemper 1965). 


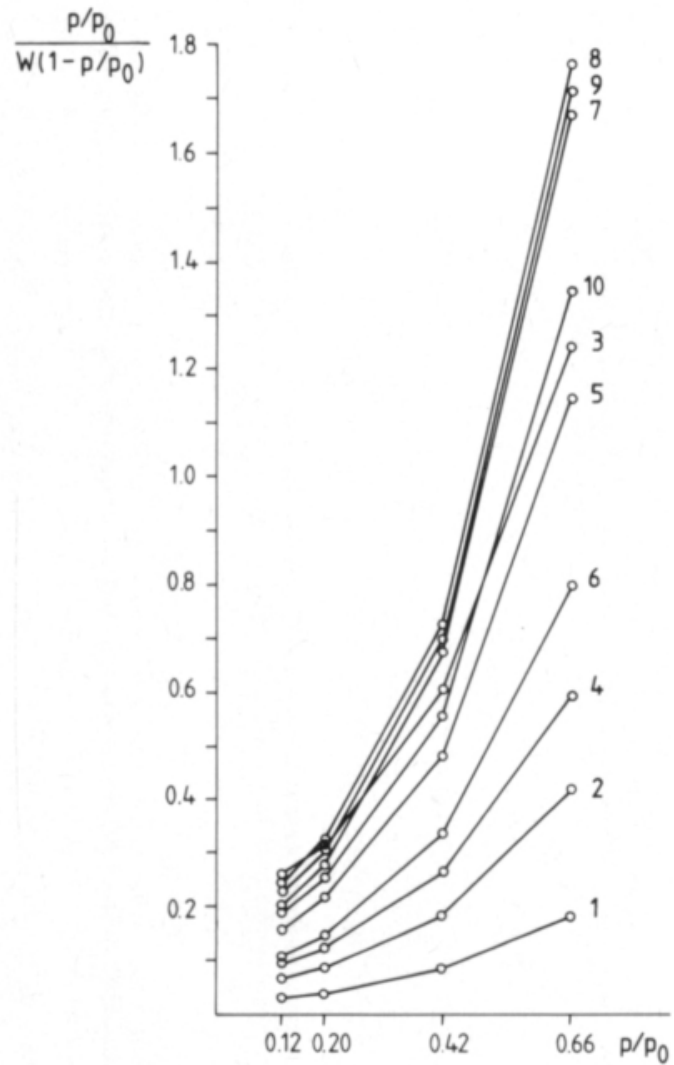

Fig. 2. BET plots for water vapor sorption on experimental soils.

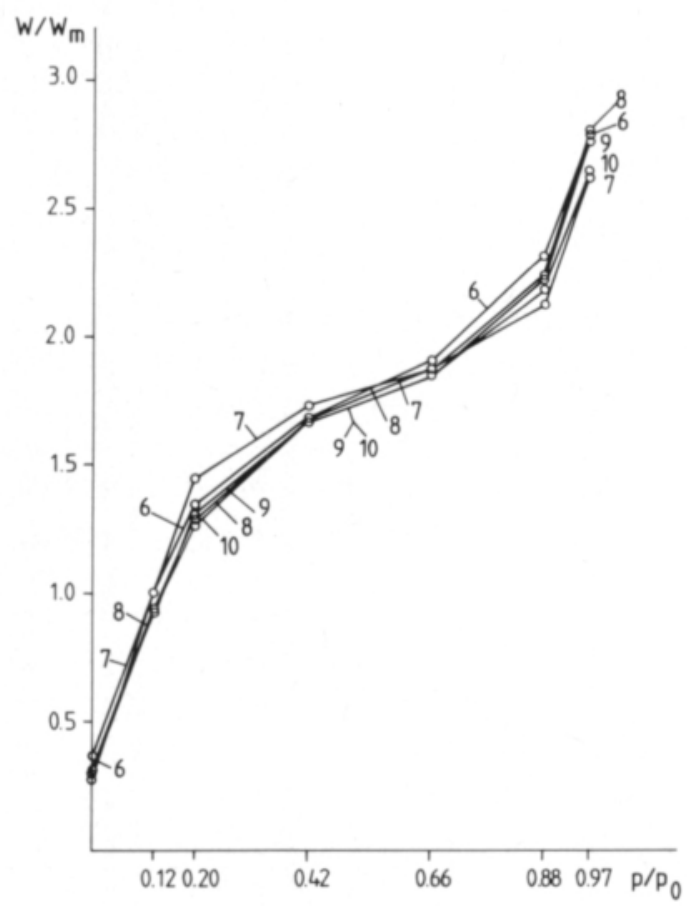

The quantities of water forming a monolayer, $\mathrm{w}_{\mathrm{m}}$, ranging from 0.59 to $5.50 \%$ of dry soil were calculated on the basis of the BET equation $\left(\mathrm{p} / \mathrm{p}_{\mathrm{o}}, 0.12-0.42\right)$ by the method of least squares. Division of the water sorption values by $\mathrm{w}_{\mathrm{m}}$ gives the thickness of the water molecule layer at different relative humidities (Fig. 3). The water monolayer coverage was formed on the surface of experimental soils at $\mathrm{p} / \mathrm{p}_{\mathrm{o}} 0.12-0.20$, soils were covered by a two-molecule layer at $\mathrm{p} / \mathrm{p}_{\mathrm{o}}$ $0.64-0.77$ (Fig. 3). Coarse soils were covered by a monolayer at a lower $\mathrm{p} / \mathrm{p}_{\mathrm{o}}$ than clay soils. The number of molecule layers at $\mathrm{p} / \mathrm{p}_{\mathrm{o}}$ 0.20 was $1.00-1.45$. The results were of the same magnitude as those obtained by NIEMINEN and KELLOMÄKI (1982) who studied water adsorption on the fine fractions of 90 till samples. In this material, the monolayer coverage was formed, on the average, at $\mathrm{p} / \mathrm{p}_{\mathrm{o}} 0.11$, range $0.03-0.39$.

The specific surface areas of experimental soils calculated on the basis of BET monolayer water adsorption, $\mathbf{w}_{\mathrm{m}}$, are given in Table 2 . The BET water areas were to some extent lower than areas calculated by water adsorp-

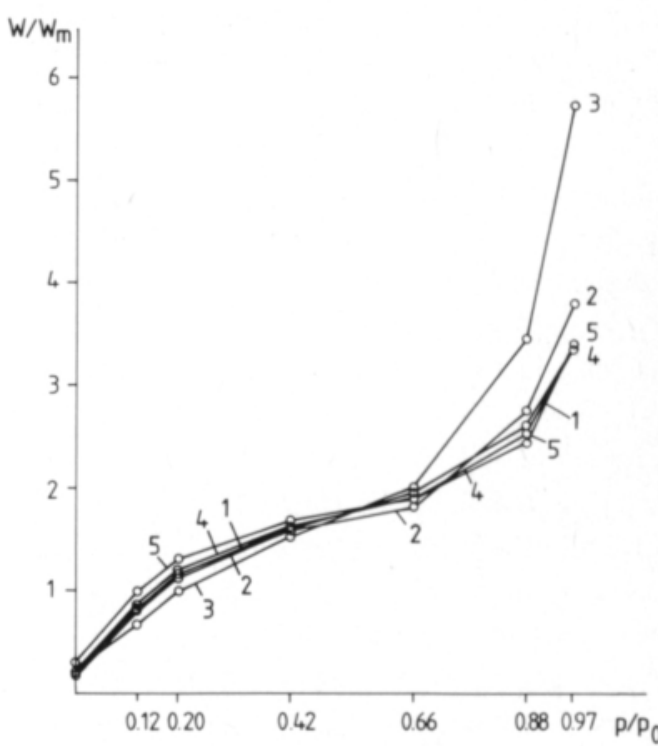

Fig. 3. Thickness of the water molecule layer adsorbed on soil at different relative humidities. 
Table 2. Surface area of soil samples.

\begin{tabular}{|c|c|c|c|c|c|c|c|c|c|}
\hline \multirow[t]{3}{*}{ Sample } & \multirow[t]{3}{*}{ Locality } & \multirow{3}{*}{$\begin{array}{l}\text { Sampling } \\
\text { depth, } \\
\mathrm{cm}\end{array}$} & \multirow[t]{3}{*}{$\underset{\%}{\text { Org. C, }}$} & \multirow{2}{*}{\multicolumn{3}{|c|}{$\begin{array}{c}\text { Particle-size } \\
\text { distribution } \\
(\mu \mathrm{m}), \%\end{array}$}} & \multicolumn{3}{|c|}{$\begin{array}{c}\text { Surface area, } \mathrm{m}^{2} / \mathrm{g} \text { dry soil } \\
\text { by adsorption of }\end{array}$} \\
\hline & & & & & & & \multirow[t]{2}{*}{ nitrogen } & \multicolumn{2}{|c|}{ water vapor } \\
\hline & & & & $<2$ & $2-20$ & $>20$ & & at $\mathrm{p} / \mathrm{p}_{\mathrm{o}} 0.20$ & BET-area \\
\hline 1 & Imatra & $20-40$ & 11.5 & 72 & 17 & 11 & 20.85 & 229.36 & 194.74 \\
\hline 2 & Viikki & $0-20$ & 5.3 & 58 & 14 & 28 & 10.01 & 102.10 & 87.75 \\
\hline 3 & Viikki & $20-40$ & 0.8 & 39 & 6 & 55 & 14.80 & 27.65 & 27.45 \\
\hline 4 & Imatra & $0-20$ & 1.1 & 28 & 41 & 31 & 6.54 & 72.32 & 58.68 \\
\hline 5 & Hyvinkää & $20-40$ & 1.3 & 19 & 47 & 34 & 8.77 & 41.12 & 30.91 \\
\hline 6 & Tohmajärvi & $0-20$ & 3.8 & 4 & 10 & 86 & 2.22 & 60.62 & 44.92 \\
\hline 7 & $n$ & $30-50$ & 1.1 & 3 & 17 & 80 & 3.62 & 31.91 & 22.06 \\
\hline 8 & Hyvinkảä & $0-20$ & 1.7 & 3 & 2 & 95 & 1.34 & 26.94 & 21.04 \\
\hline 9 & Viikki & $0-20$ & 3.0 & 2 & 2 & 96 & 0.27 & 28.36 & 21.61 \\
\hline 10 & Vaala & $20-40$ & 1.3 & 1 & 3 & 96 & 0.75 & 35.10 & 27.57 \\
\hline
\end{tabular}

tion at $\mathrm{p} / \mathrm{p}_{\mathrm{o}} 0.20$ (Table 2). On the average, the BET areas were $80 \%$ of the areas determined by sorption at $\mathrm{p} / \mathrm{p}_{\mathrm{o}} \quad 0.20$. The relationship between water areas was as follows: $\mathrm{H}_{2} \mathrm{O}$-area $\left(\mathrm{p} / \mathrm{p}_{\mathrm{o}} 0.20\right)\left(\mathrm{m}^{2} / \mathrm{g}\right)=3.36+1.16$ $\mathrm{H}_{2} \mathrm{O}$-area $(\mathrm{BET})\left(\mathrm{m}^{2} / \mathrm{g}\right)(\mathrm{r}=0.999 * * *, \mathrm{n}=$ 10).

The application of the BET equation to the sorption of $\mathrm{N}_{2}$ is a recognized method for determination of surface area of soils and clays. Weakly adsorbed nitrogen will not penetrate the interlayer surfaces of clay minerals. Because a sample has to be »degassed" of any sorbed molecules before determination of surface area, all adsorbed water is lost. This causes any expanding clay lattice to collapse and the non-polar nitrogen gas cannot subsequently enter interlayer areas. Water, which is polar, is strongly adsorbed and it penetrates the interlayers leading to higher values for surface area. The nitrogen area will yield a measure of the external surface area, whereas the water area will give information about the total surface area, internal and external included (van OLPHEN 1975).

The nitrogen BET areas of experimental soils were in general much lower than the water areas (Table 2). The only exception was the deeper layer soil No. 3 the $\mathrm{N}_{2}$-area of which was about half the water areas. The relationship between $\mathrm{N}_{2}$ - and water areas was not very close: $\mathrm{N}_{2}$-area $\left(\mathrm{m}^{2} / \mathrm{g}\right)=1.64+$
$0.08 \mathrm{H}_{2} \mathrm{O}$-area $\left(\mathrm{p} / \mathrm{p}_{\mathrm{o}} 0.20\right)\left(\mathrm{m}^{2} / \mathrm{g}\right)\left(\mathrm{r}=0.74^{*}\right.$, $\mathrm{n}=10)$ and $\mathrm{N}_{2}$-area $\left(\mathrm{m}^{2} / \mathrm{g}\right)=1.74+0.10$ $\mathrm{H}_{2} \mathrm{O}$-area $(\mathrm{BET})\left(\mathrm{m}^{2} / \mathrm{g}\right)\left(\mathrm{r}=0.77^{* *}, \mathrm{n}=\right.$ 10).

In a larger soil material $(n=60), 84 \%$ of the variation in surface area determined by water adsorption at $\mathrm{p} / \mathrm{p}_{\mathrm{o}} 0.20$ was explained by organic carbon and clay content (NISKANEN and MÄNTYLAHTI 1987 a). In this small material the correlation coefficient between water area $\left(\mathrm{p} / \mathrm{p}_{\mathrm{o}}, 0.20\right)$ and organic carbon content was $\mathrm{r}=0.94 * * *(\mathrm{n}=10)$ and that between water area and clay content $r=$ $0.81^{* *}$. The correlation coefficient between $\mathrm{N}_{2}$-area and clay content was $\mathrm{r}=0.92^{* * *}$ and that between $\mathrm{N}_{2}$-area and organic carbon content $\mathrm{r}=0.63^{*}$.

$\mathrm{H}_{2} \mathrm{O}$-areas were closely related to the organic carbon content, while $\mathrm{N}_{2}$-areas seemed to be related primarily to the soil clay content. According to DobRZAŃsKi et al. (1971), the $\mathrm{N}_{2}$-area correlates positively with clay content and negatively with humus content. The values of the external surface areas are lower in the soil with organic substances and higher after their removal, while the total surface area is higher in the presence of organic substances than in their absence (DoBRZAŃSKı et al. 1972). The negative influence of the organic substances on the external surface area is greater, with a higher content of clay, because organic substances 
block micropores. This trend is observable also in the present material, for instance, when soils Nos 2 and 3 are compared (Table 2). Soil No. 2 with higher organic carbon and clay content had a lower $\mathrm{N}_{2}$-area and higher $\mathrm{H}_{2} \mathrm{O}$ area than soil No. 3 with lower clay and carbon content.

Adsorption of polar molecules like water provides an experimentally simpler method for determination of surface area than $\mathrm{N}_{2}$ adsorption. Polar molecules offer the advantage of exploring both the external and internal area. The disadvantage of polar molecules is their interaction with the surface and between themselves. Water molecules are attracted to the bare exchangeable cations and cluster round them, which implies overlapping of the monolayer and multilayer processes (Greenland and Mott 1978). In agricultural soils the contribution of both organic matter and clay content is a major advantage. Another advantage is that it makes unnecessary the degassing of soil which can affect soil properties.

Acknowledgement. The authors wish to thank Dr. Pertti Nieminen, Tampere University of Technology, for analysis of surface area by nitrogen gas adsorption.

\section{References}

ANON, 1984. Handbook of chemistry and physics 65th Ed. Boca Raton, Florida.

Brunauer, G., Emmett, P.H. \& Teller, E. 1938. Adsorption of gases in multimolecular layers. J. Amer. Chem. Soc. 60: 309-319.

Dechnik, I. \& Stawińskı, J. 1970. Determination of the total surface area of soils on the basis of one measurement. Polish J. Soil Sci. 3: 15-20.

Dobrzanski, B., Stawiński, J. \& Walczak, R. 1971. The availability of the method of thermal desorption of nitrogen for estimation of the surface area of soil material. Polish J. Soil Sci. 4: 81-87.

-, DechniK, I. \& Stawiñski, J. 1972. Correlation between the soil surface-area and humus compounds in the soil. Polish J. Soil Sci. 5: 99-102.

Elonen, P. 1971. Particle-size analysis of soil. Acta Agr. Fenn. 122: 1-122.

GÁl, S. 1967. Die Methodik der Wasserdampf-Sorptionsmessungen. Berlin, $139 \mathrm{p}$.

Graham, E. 1948. Determination of soil organic matter by means of a photoelectric colorimeter. Soil Sci. 65 : 181-183.

Greenland, D. J. \& Mott, C.J.B. 1978. Surfaces of soil particles. The chemistry of soil constituents (eds. Greenland, D.J. \& Hayes, M.H.B.), p. 321-353. London.

GregG, S.J. \& Sing, K.S.W. 1982. Adsorption, surface area and porosity. 2nd ed., London, 303 p.

Hillel, D. 1971. Soil and water. Physical principles and processes. 288 p. New York.

Karathanasis, A.D. \& Hajek, B.F. 1982. Quantitative evaluation of water adsorption on soil clays. Soil Sci. Soc. Am. J. 46: 1321-1325.
Mortland, M.M. \& Kemper, W.D. 1965. Specific Surface. Agronomy 9, 1: 532-544.

Nieminen, P. 1985. Moreenin hienoaineksen laatu ja sen vaikutus routimisherkkyyteen (The quality of the fine fractions of till and its influence on frost susceptibility). Tampereen teknillisen korkeakoulun julkaisu 34.81 p. Tampere.

— \& KellomäKı, A. 1982. Veden adsorptio moreenien hienoainekseen (Adsorption of water on the fine fractions of Finnish tills). Tampereen teknillisen korkeakoulun rakennusgeologian laitoksen julkaisu 9. 24 p. Tampere.

Niskanen, R. \& Mántylahtı, V. 1987 a. Determination of soil specific surface area by water vapor adsorption. II Dependence of soil specific surface area on clay and organic carbon content. J. Agric. Sci. Finl. 59: 67-72.

— \& Mantrlahtı, V. 1987 b. Determination of soil specific surface area by water vapor adsorption. I Drying of soil samples. J. Agric. Sci. Finl. 59: 63-65.

Olphen, H. van 1975. Water in soils. Soil components 2. Inorganic components (ed. Gieseking, J.E.), p. 497-527. Berlin.

OrChiston, H.D. 1953. Adsorption of water vapor: I. Soils at $25{ }^{\circ} \mathrm{C}$. Soil Sci. 76: 453-465.

PurI, B.R. \& Murarı, K. 1963. Studies in surface area measurements of soils: 1. Comparison of different methods. Soil Sci. 96: 331-336.

QUiRK, J.P. 1955. Significance of surface areas calculated from water vapor sorption isotherms by use of the B.E.T. equation. Soil Sci. 80: 423-430.

Ms received October 16, 1987 


\title{
SELOSTUS
}

\section{Maan ominaispinta-alan määrittäminen}

vesihöyryn adsorption avulla

III Vesihöyryn ja typpikaasun adsorption avulla määritettyjen ominaispinta-alojen vertailu

\author{
Raina Niskanen ${ }^{1}$ ja Väinö Mäntylahti ${ }^{2}$ \\ 'Maanviljelyskemian laitos, Helsingin yliopisto, \\ $00710 \mathrm{Helsinki}$ \\ 2 Viljavuuspalvelu Oy, Vellikellontie 4, \\ $00410 \mathrm{Helsinki}$
}

Kymmenen maanäytteen (savespitoisuus $1-72 \%$, orgaanisen hiilen pitoisuus $0.8-11.5 \%$ ) ominaispinta-ala mäaritettiin vesihöyryn ja typpikaasun adsorption avulla. Vesihöyryn adsorptiosta $12-42 \%$ suhteellisessa kosteudessa BET-yhtälön avulla lasketut ominaispinta-alat $\left(21-195 \mathrm{~m}^{2} / \mathrm{g}\right)$ olivat keskimaaarin $80 \%$ ominaispintaaloista, jotka saatiin $20 \%$ suhteellisessa kosteudessa tapahtuneen vesihöyryn adsorption perusteella (27$229 \mathrm{~m}^{2} / \mathrm{g}$ ). BET-yhtälön avulla laskettu yhden molekyylin paksuinen vesikerros muodostui maan pinnalle
$12-20 \%$ suhteellisessa kosteudessa. BET-yhtälön avulla lasketun ja $20 \%$ suhteellisessa kosteudessa määritetyn ominaispinta-alan vălinen korrelaatio oli tiukka. Typpikaasun adsorption avulla määritetyt ominaispinta-alat $\left(0.3-21 \mathrm{~m}^{2} / \mathrm{g}\right)$ eivăt kovin kiinteästi korreloineet vesihöyryn avulla määritettyjen pinta-alojen kanssa. Vesihöyryn adsorption avulla määritetyt pinta-alat riippuivat voimakkaasti maan orgaanisen hiilen pitoisuudesta kun taas typpikaasun adsorption avulla määritetyt pinta-alat olivat ensisijaisesti riippuvaisia saveksen pitoisuudesta. 